\title{
Laboratory Assessment of Early Dietary, Subclinical Zinc Deficiency: A Model Study on Weaning Rats
}

\author{
JACOBUS P. VAN WOUWE, MARCEL VELDHUIZEN, JEROEN J. M. DE GOEIJ, AND \\ CORNELIS J. A. VAN DEN HAMER
}

Department of Paediatrics, State University at Leiden, 2300 RC Leiden [J.P.V.W.] and Department of Radiochemistry, Interfaculty Reactor Institute, Delft University of Technology, 2629 JB Delft [J.P.V.W., M.V., J.J.M.D.G., C.J.A.V.d.H.J, the Netherlands

\begin{abstract}
Male weaning rats were pair-fed a low-zinc diet or a control diet. After $10 \mathrm{~d}$, the animals fed the lowzinc diet showed physiologic signs of deficiency; however, they showed no clinical symptoms. Their estimated whole body zinc was $25 \mu \mathrm{mol}$ versus $39 \mu \mathrm{mol}$ for the controls. The ${ }^{65} \mathrm{Zn}$ absorption increased 2 -fold and the tissue distribution altered: muscle and erythrocytes contained more, small intestine and liver less activity at $0.5 \mathrm{~h}$ postdose. In vitro, the erythrocyte ${ }^{65} \mathrm{Zn}$ uptake rate increased also. The ${ }^{65} \mathrm{Zn}$ uptake experiments required small quantities of erythrocytes. The difference observed between the deficient and control cells was significant and showed little overlap. The increase of the ${ }^{65} \mathrm{Zn}$ uptake from a medium was not affected when the animals underwent endotoxin exposure $24 \mathrm{~h}$ before, as was reported to occur in whole blood ${ }^{65} \mathrm{Zn}$ uptake. Therefore, we suggest the in vitro erythrocyte ${ }^{65} \mathrm{Zn}$ uptake, performed in a standardized, near physiologic medium, to detect early, subclinical zinc deficiency. (Pediatr Res 29: 391-395, 1991)
\end{abstract}

The occurrence of zinc deficiency is not well defined. Its clinical signs are often milder than those that the patients with acrodermatitis enteropathica suffer from. This inborn error of zinc absorption causes severe chronic deficiency. Yet, the extent of its symptoms varies but it is not understood why. To affirm the diagnosis, elaborate tests have been designed to demonstrate the low absorption using radioactive ${ }^{65} \mathrm{Zn}$ (1). A reliable parameter to estimate the extent of the deficiency is not available. Besides the chronic deficiency in acrodermatitis enteropathica, other zinc deficiencies are believed to occur in otherwise wellnourished children. In a group of children suffering from recurrent upper respiratory tract infection, evidence of subacute deficiency was demonstrated. In another group with acute diarrhea, acute zinc deficiency was observed. Growth was hampered in both groups of children. Walravens and coworkers $(2,3)$ have proven the existence of a growth-limiting syndrome caused by subclinical zinc deficiency; in supplemented children, growth was enhanced. In the absence of a reliable test, the response to zinc treatment has been used to detect deficiency in children.

In laboratory animals, various degrees of dietary deficiency can be induced. They serve as a model to study the identification of a suitable parameter that reflects the degree of deficiency.

Received July 12, 1990; accepted November 12, 1990.

Correspondence and reprint requests: J. P. Van Wouwe, Department of Radiochemistry, Interfaculty Reactor Institute, Delft University of Technology, Mekelweg 15, $2629 \mathrm{JB}$ Delft, the Netherlands.

Supported by Grant 28-1549 of the Dutch Prevention Fund, The Hague, the Netherlands.
From earlier results, we advocate the use of plasma sp act $\left({ }^{65} \mathrm{Zn}\right.$ per total $\mathrm{Zn}$ ) after administration of ${ }^{65} \mathrm{Zn}$ to detect deficiency (4). The use of ${ }^{65} \mathrm{Zn}$ in vivo is generally limited. By a variant experimental design, we induced subclinical deficiency in animals (5). In the present study, we monitored the zinc status and its regulation in subclinically deficient weaning rats. The zinc status was characterized not only by tissue zinc contents, tissue ${ }^{65} \mathrm{Zn}$ distribution, and $\mathrm{sp}$ act, but also by in vitro erythrocytic ${ }^{65} \mathrm{Zn}$ uptake experiments (6). Regulation of the zinc status was measured by whole body ${ }^{65} \mathrm{Zn}$ absorption, excretion, and turnover. On the basis of the results, we evaluated the suitability of the parameters to detect subclinical deficiency.

\section{MATERIALS AND METHODS}

Animals and diets. Male weaning Wistar rats (special pathogen-free; strain $\mathrm{Cpb} / \mathrm{WU}$; random bred; CPB-Harlan, Zeist, the Netherlands), weighing approximately $50 \mathrm{~g}$, were randomly assigned to deficient $(30 \mu \mathrm{mol} \mathrm{Zn} / \mathrm{kg})$ or control $(150 \mu \mathrm{mol} \mathrm{Zn} /$ $\mathrm{kg})$ semisynthetic Interfaculty Reactor Institute OvalbuminBased diets (Hope Farms, Woerden, the Netherlands) (for diet composition, see 6). Pair-feeding between control $(n=60)$ and experimental $(n=60)$ animals was maintained during the entire study. Food was removed the night before ${ }^{65} \mathrm{Zn}$ was offered and also before the animals were killed. The rats were individually housed in Macrolon cages with stainless steel lids (Techniplast 1700/1; Gazzada, Buguggiate, Italy) and the rats had free access to double-distilled water with $0.1-0.2 \mu \mathrm{mol} \mathrm{Zn} / \mathrm{L}$ (by analysis). The cages were placed in an air-conditioned room $\left(20 \pm 1^{\circ} \mathrm{C}\right)$ with a relative humidity of $55 \%$. A fixed day-night rhythm was applied (light from 6 to $18 \mathrm{~h}$ ). Body weight was recorded daily before feeding.

Zinc status. After being fed the experimental diets for $10 \mathrm{~d}, 12$ animals of each group were killed under $\mathrm{CO}_{2}$ anesthesia. Blood was collected and dissection of the carcass was performed with stainless steel instruments. The reagents used were of analytical grade and all utensils were rinsed with $5 \% \mathrm{HCl}$. Samples of the left hepatic lobe, the pancreas, the duodenum and adjacent jejunum over a total length of $5 \mathrm{~cm}$, the right tibia, the flexor digitorum muscle, and fur and hair of the abdominal region were prepared. The lumen of the proximal small intestine sample was first rinsed with saline. The tissues were weighed and freeze-dried for $48 \mathrm{~h}$. Then they were dissolved with $65 \%$ nitric acid for $1 \mathrm{~h}$ at $70^{\circ} \mathrm{C}$ (Suprapur; E. Merck, Darmstadt, Germany) and subsequently with $30 \%$ hydrogen peroxide (Aristar; BDH Chemicals, Poole, UK). The plasma was separated by centrifugation at 1300 $\times g$ at $4^{\circ} \mathrm{C}$ for $30 \mathrm{~min}$, the buffy coat was removed, and the erythrocytes were washed with saline at $4^{\circ} \mathrm{C}$ (double-distilled water and Baker Analysed NaCl; Baker, Deventer, the Netherlands). 
Zinc concentration in urine, plasma, and ashed tissues was determined by atomic absorption spectrometry (no. 2380; Perkin Elmer, Norwalk, CT) in duplicate. The amount of zinc in whole tissues was calculated using the fractional weight of the tissues as derived from the literature (7) and the dry weight/wet weight ratios as determined in earlier experiments (Table 1). As shown in Table $1,83.5 \%$ of the animal weight was accounted for. Whole body zinc was approximated by totaling the zinc inventories of these tissues and multiplying the resulting sum by the factor $100 /$ 83.5. The urine of six animals of each group was collected over $10 \mathrm{~d}$. In addition to zinc, creatinine and total nitrogen were determined in the pooled urine by routine clinical chemical methods.

Regulation of zinc status. ${ }^{65} \mathrm{Zn}$ studies were started in another 12 animals of each group on experimental d 6. First, the apparent retention, the biologic half-life, and the absorption were determined. Half (six rats) of each group were given ${ }^{65} \mathrm{Zn}(0.5 \mu \mathrm{mol}$ $\mathrm{Zn} / 70 \mathrm{~g}$ body $\mathrm{wt}$ ) by orogastric tube. The other half (six rats) of each group were injected intraperitoneally with a smaller dose $\left(0.05 \mu \mathrm{mol}{ }^{65} \mathrm{Zn} / 70 \mathrm{~g}\right.$ body $\left.\mathrm{wt}\right)$. In all 12 animals, whole-body counting was performed on d 0 ( $2 \mathrm{~h}$ after dose, this activity was set equal to $100 \%$ dose) and then daily from d 13 to 21 with a specially designed whole-body counter for rats (8) consisting of a container filled with a scintillation liquid (pseudo-cumene) and fitted with a centrally positioned "well" $(0.06 \times 0.20 \mathrm{~m})$. Measurements were calibrated daily with a ${ }^{65} \mathrm{Zn}$ standard and corrections for decay and background were made.

Table 1. Body wt (\%) and dry to wet wt ratios (mean $\pm S D$ ) of tissues from male weaning rats*

\begin{tabular}{lcc}
\hline \multicolumn{1}{c}{ Tissue } & $\begin{array}{c}\% \text { of } \\
\text { body wt }\end{array}$ & $\begin{array}{c}\text { Dry/wet wt } \\
\text { ratio }\end{array}$ \\
\hline Plasma & 4.6 & \\
Erythrocytes & 3.1 & $0.30 \pm 0.03$ \\
Liver & 2.9 & $0.35 \pm 0.03$ \\
Bone & 14 & $0.80 \pm 0.07$ \\
Fur & 20 & $0.75 \pm 0.06$ \\
Muscle & 38 & $0.20 \pm 0.02$ \\
Pancreas & 0.3 & $0.35 \pm 0.03$ \\
Small intestinet & 0.6 & $0.20 \pm 0.02$ \\
Total & 83.5 & \\
\hline
\end{tabular}

* Rats were pair-fed a zinc-deficient or control diet for $10 \mathrm{~d}$. The body weight of tissues, in \% of the total body weight as derived from the literature, and the determined ratios of their tissue dry and wet weights $(n=12)$ are shown.

†Proximal $5 \mathrm{~cm}$.

Table 2. Body wt and urinary excretions during experimental period (mean $\pm S D, n=12$ )*

\begin{tabular}{lcccc}
\hline & Deficient & Control & $p$ & O† \\
\hline Body wt $(\mathrm{g}):$ & & & & \\
Start & $49 \pm 3$ & $50 \pm 3$ & NS & 99 \\
On d 9 & $52 \pm 3$ & $69 \pm 9$ & $\ddagger$ & 0 \\
On d 10§ & $49 \pm 3$ & $66 \pm 8$ & $\ddagger$ & 0 \\
Growth $(\mathrm{g} / \mathrm{d})$ & $0.3 \pm 0.1$ & $1.9 \pm 0.6$ & $\ddagger$ & 6 \\
Urine excretion: & & & & \\
Zn $(\mu$ mol/d) & $0.05 \pm 0.02$ & $0.08 \pm 0.03$ & NS & 93 \\
Creatinine $(\mu \mathrm{mol} / \mathrm{d})$ & $8.5 \pm 2.7$ & $7.6 \pm 5.3$ & NS & 79 \\
Zn/creatinine $\times 10^{3}$ & $9 \pm 6$ & $10 \pm 3$ & NS & 66 \\
Total N $(\mathrm{mmol} ;$ & $7.0 \pm 1.4$ & $3.2 \pm 1.3$ & $\|$ & 0 \\
$\quad$ d 10) & & & & \\
Zn/total N $\times 10^{6}$ & $7 \pm 5$ & $25 \pm 12$ & $\|$ & 9 \\
\hline
\end{tabular}

* Male weaning rats were pair-fed a zinc-deficient or control diet for $10 \mathrm{~d}$.

$\dagger$ Percentage overlap.

$\ddagger p<0.001$ (analysis of variance).

$\S$ After an overnight fast.

$\| p<0.01$ (analysis of variance).
The apparent retention, $\mathrm{R}_{0}$, was calculated from the linear fit versus time of the countings between $d 13$ and 21 of the animals injected with ${ }^{65} \mathrm{Zn}$ expressed as natural logarithm of the dose in $\%$ :

$$
\ln \mathrm{R}_{\mathrm{t}}=-\mathrm{at}+\ln \mathrm{R}_{0}
$$

where $R_{t}$ is the activity in the animal in \% dose at time $t$, a is a constant, $t$ is the time in days, and $R_{0}$ is the activity extrapolated to $t=0$, the apparent retention in $\%$ dose. The biologic half-life, $T_{b}$, was calculated from $a$ :

$$
\mathrm{T}_{\mathrm{b}}=\ln 2 / \mathrm{a}
$$

The apparent absorption, $A_{0}$, was calculated analogously in the animals that received the ${ }^{65} \mathrm{Zn}$ by intubation:

$$
\ln A_{t}=-b t+\ln A_{0}
$$

The ratio of apparent absorption and apparent retention is the true absorption, A, being:

$$
A=\frac{A_{0}}{R_{0}}
$$

In vivo ${ }^{65} \mathrm{Zn}$ distribution. In the third experiment, another 12 animals of each group were killed $10 \mathrm{~d}$ after starting the Interfaculty Reactor Institute Ovalbumin-Based diets and $30 \mathrm{~min}$ after an oral dose $(0.5 \mu \mathrm{mol} \mathrm{Zn} / 70 \mathrm{~g}$ body wt $)$ of ${ }^{65} \mathrm{Zn}(27 \mathrm{GBq} / \mathrm{mol}$; The Radiochemical Center, Amersham, UK). ${ }^{65} \mathrm{Zn}$ activities in the tissues given in Table 1 (except fur) and the content rinsed from the proximal small intestine were measured with a gammacounter at a window setting of $960-1240 \mathrm{keV}$. The duration of countings was adjusted to assure an error due to counting statistics of $<1 \%$. The total ${ }^{65} \mathrm{Zn}$ activity in the tissues was calculated using the fractional weight distribution (Table 1). Dose distribution and absorbed ${ }^{65} \mathrm{Zn}$ activity distribution were calculated separately and averaged for the two groups of 12 animals each.

In vitro erythrocyte ${ }^{65} \mathrm{Zn}$ uptake. Of the remaining animals, 18 of each group were killed on d 10. Samples of $0.3 \mathrm{~mL}$ of pooled and washed erythrocytes were incubated in vitro with either 0.3 $\mathrm{mL}{ }^{65} \mathrm{Zn}$ tracer in pooled plasma from the deficient (total zinc $11 \mu \mathrm{mol} / \mathrm{L})$ or control animals $(22 \mu \mathrm{mol} / \mathrm{L})$, respectively. The incubation was carried out in a shaking water bath at $37^{\circ} \mathrm{C}$ for 1 $\mathrm{h}$ and was stopped by cooling in ice water and centrifugation at $4^{\circ} \mathrm{C}$. The erythrocytes were washed three times with saline, after which no activity was left in the last supernatant. Erythrocytes of other animals were incubated in $7.6 \mu \mathrm{mol} / \mathrm{L}\left[{ }^{65} \mathrm{Zn}\right]-\mathrm{Zn}_{2} \mathrm{Cl}$ medium in a ratio $4: 6(\mathrm{vol} / \mathrm{vol})$. This medium was otherwise composed of $145 \mathrm{mmol} / \mathrm{L} \mathrm{NaCl}, 6 \mathrm{mmol} / \mathrm{L} \mathrm{KCl}, 2 \mathrm{mmol} / \mathrm{L}$ $\mathrm{MgCl}_{2}, 5.6 \mathrm{mmol} / \mathrm{L}$ glucose, $40 \mathrm{~g} / \mathrm{L}$ albumin (fraction $\mathrm{V}$ no. 12659; Behring Diagnostics, La Jolla, CA) and $10 \mathrm{mmol} / \mathrm{L} N-2$ hydroxyethylpiperazine- $N^{\prime}$-2-ethanesulfonic acid buffer (Sigma Chemical Co., St. Louis, MO).

The incubated pooled cells of each group were hemolysed by repeated freezing of the pellet during $5 \mathrm{~min}$ in a mixture of acetone and $\mathrm{CO}_{2}$-ice. The frozen pellet was melted at room temperature. No intact cells were seen in a Buerker hemocytometer chamber. The cell ghosts were pelleted by centrifugation of the lysate $(2400 \times g, 20 \mathrm{~min})$ and their ${ }^{65} \mathrm{Zn}$ activity counted.

Finally, to test the possible effect of endotoxin on erythrocyte ${ }^{65} \mathrm{Zn}$ uptake, cells of the remaining six rats of each diet group were collected. These animals were killed $24 \mathrm{~h}$ after intraperitoneal injection of Escherichia coli endotoxin (lipopolysaccharide B: $2 \mathrm{mg} / \mathrm{kg}$ body wt; dissolved in $0.5 \mathrm{~mL}$ saline; 055:B5; Sigma Chemical Co.).

All statistical comparisons were performed by analysis of variance and regression analysis. SD were calculated by the usual error propagation rules. Sensitivity and specificity were calculated by the overlap index according to Hartz (9). 
Table 3. Zinc status of male weaning rats pair-fed zinc-deficient or control diets for $10 \mathrm{~d}$ as indicated by tissue zinc concentration ( $\mu \mathrm{mol} / \mathrm{g}$ dry wt) and tissue zinc content ( $\mu \mathrm{mol} /$ total tissue) (mean $\pm S D ; n=12$ )

\begin{tabular}{|c|c|c|c|c|c|c|}
\hline & \multicolumn{2}{|c|}{ Deficient } & \multicolumn{2}{|c|}{ Control } & \multirow[b]{2}{*}{$p$} & \multirow[b]{2}{*}{$\mathrm{O}^{*}$} \\
\hline & $\begin{array}{c}\text { Zinc } \\
\text { concentration }\end{array}$ & $\begin{array}{c}\text { Zinc } \\
\text { content }\end{array}$ & $\begin{array}{c}\text { Zinc } \\
\text { concentration }\end{array}$ & $\begin{array}{c}\text { Zinc } \\
\text { content }\end{array}$ & & \\
\hline Small intestine & $1.2 \pm 0.1$ & 0.072 & $1.6 \pm 0.2$ & 0.10 & $\dagger$ & 7 \\
\hline Plasma & $0.011 \pm 0.003$ & 0.026 & $0.022 \pm 0.007$ & 0.066 & $f$ & 16 \\
\hline Erythrocytes & $0.64 \pm 0.34$ & 0.28 & $0.63 \pm 0.25$ & 0.36 & NS & 85 \\
\hline Liver & $1.5 \pm 0.3$ & 0.78 & $1.6 \pm 0.4$ & 1.06 & NS & 94 \\
\hline Pancreas & $0.91 \pm 0.08$ & 0.05 & $1.5 \pm 0.2$ & 0.10 & + & 0 \\
\hline Fur & $1.5 \pm 0.3$ & & $0.9 \pm 0.3$ & & + & 24 \\
\hline Skin & & 3.5 & & 2.6 & & \\
\hline Hair & $2.8 \pm 0.6$ & 1.4 & $2.7 \pm 0.5$ & 1.8 & NS & 84 \\
\hline Bone & $1.3 \pm 0.2$ & 11 & $2.8 \pm 0.4$ & 20 & $\ddagger$ & 0 \\
\hline Muscle & $0.9 \pm 0.1$ & 3.8 & $1.2 \pm 0.2$ & 5.9 & $t$ & 23 \\
\hline Total $\mathrm{Zn}$ content $(\mu \mathrm{mol})$ & & 21 & & 32 & $\ddagger$ & \\
\hline Whole body zinc & & $25 \S$ & & $39 \S$ & $\ddagger$ & 6 \\
\hline
\end{tabular}

* Percentage overlap.

$\dagger p<0.01$ (analysis of variance) for zinc concentrations.

$\ddagger p<0.001$ (analysis of variance) for zinc concentrations.

$\S$ Taking into account that $83.5 \%$ of the animal was sampled and that for the whole body a correction factor of $100 / 83.5$ was applied.

Table 4. Fate of oral dose of ${ }^{65} \mathrm{Zn}$ in male weaning rats pair-fed zinc-deficient or control diets for $10 d$ (mean $\pm S D ; n=6$ )

\begin{tabular}{lclcc}
\multicolumn{4}{c}{$($ mean $\pm S D ; n=6)$} \\
\hline & Deficient & Control & $p$ & $\mathrm{O}^{*}$ \\
\hline Retention & & & & \\
Apparent retention (\%) & $100 \pm 1$ & $94 \pm 2$ & $\dagger$ & 5 \\
$\quad$ Biologic half-life (d) & $95 \pm 7$ & $53 \pm 16$ & $\ddagger$ & 0 \\
Absorption & & & & \\
At 30 min (\%) & $92 \pm 10 \S$ & $49 \pm 14 \S$ & $\ddagger$ & 14 \\
Apparent absorption (\%) & $78 \pm 8$ & $55 \pm 4$ & $\mathrm{NS}$ & 22 \\
$\quad$ True absorption (\%) & $78 \pm 8$ & $55 \pm 4$ & $\dagger$ & 22 \\
\hline
\end{tabular}

* Percentage overlap.

$\dagger p<0.01$ (analysis of variance).

$\ddagger p<0.001$ (analysis of variance).

$\S$ Taking into account that $83.5 \%$ of the animal was sampled and that for the whole body a correction factor of $100 / 83.5$ was applied.

\section{RESULTS AND DISCUSSION}

Characterization of deficiency. The animals fed the deficient diet ate less than the controls. They determined the food intake of the controls at pair-feeding. In $9 \mathrm{~d}, 60 \mathrm{~g}$ food per animal were consumed. At the end of the experiment, differences in body weight between the two groups were significant (Table 2). Normal growth of animals of this size fed commercial food (different composition and $600 \mu \mathrm{mol} \mathrm{Zn}$ per $\mathrm{kg}$ ) ad libitum is $2.6 \pm 1.0 \mathrm{~g} /$ $\mathrm{d}$ (CPB-Harlan). Thus, pair-feeding limited the food intake of the controls and resulted in reduction in growth by approximately $25 \%$. Urine creatinine remained unaltered; total nitrogen excretion increased gradually in the deficient group. Early deficiency causes growth retardation with low utilization of dietary protein.

In deficiency, the zinc status and its regulation altered. The zinc concentrations decreased in bone, pancreas, and plasma, and the concentration in fur increased (Table 3). Bone and pancreas levels indicate the dietary deficiency best, showing higher significance and no overlap. The whole-body zinc was 25 $\mu \mathrm{mol}$, compared with $39 \mu \mathrm{mol}$ in the controls. This is mainly due to a decrease of bone zinc. In the previous study, which lasted longer (4), the bone zinc decreased further to $7.4 \mu \mathrm{mol}$ in the total skeleton on $\mathrm{d} 21$, compared with $19.6 \mu \mathrm{mol}$ in the controls.

The results of the whole-body counting as a function of time after the oral ${ }^{65} \mathrm{Zn}$ show increased absorption and retention in deficient animals (Table 4). When measuring the ${ }^{65} \mathrm{Zn}$ activities in tissues $30 \mathrm{~min}$ after a similar oral dose, the ${ }^{65} \mathrm{Zn}$ activity was higher in the tissues sampled, except in liver and small intestine (Table 5). Corresponding higher tissue $\mathrm{sp}$ act were recorded, except in the small intestine and liver (Table 6). Inasmuch as no activity could be rinsed from the intestinal lumen 30 min after ingestion, it is assumed that the sum of activity of all tissues reflects the absorption, if corrected for sampling only $83.5 \%$ of the animal weight. The absorption at $30 \mathrm{~min}$ was $92 \%$ (Table 5). This average value exceeds the true absorption calculated from whole-body countings although due to the error margins involved the difference is not significant. Between the tissues, there are differences implying that homogenous distribution has not been reached during the $30 \mathrm{~min}$ postdose. Increased sp act is the result of increased ${ }^{65} \mathrm{Zn}$ uptake, a compensation mechanism of the deficiency. Liver and small intestine do not seem to compensate, bone and muscle compensate only a little, and plasma, pancreas, and erythrocytes compensate for the deficiency immediately.

Each animal ate $60 \mathrm{~g}$ food in $9 \mathrm{~d}$. The animals were metabolically in steady state. The oral ${ }^{65} \mathrm{Zn}, 0.5 \mu \mathrm{mol} / 70 \mathrm{~g}$ body wt, is in the range of the daily amount offered in the diet $(\sim 7 \pm 2 \mathrm{~g})$, viz. $0.2 \pm 0.1 \mu \mathrm{mol} \mathrm{Zn/50} \mathrm{body} \mathrm{wt}$ and $1.1 \pm 0.3 \mu \mathrm{mol} / 65 \mathrm{~g}$ in the two groups, respectively.

In summary, the animals fed the low-zinc diet showed physiologic signs of deficiency besides the growth retardation and low utilization of dietary protein. However, they showed no other clinical signs of deficiency such as skin defects (5). The absorption of ${ }^{65} \mathrm{Zn}$ was doubled and its tissue distribution altered: increased sp act is shown in plasma, pancreas and erythrocytes.

In vitro experiments. Fresh erythrocytes were incubated in vitro with ${ }^{65} \mathrm{Zn}$-labeled plasma. The ${ }^{65} \mathrm{Zn}$ uptake rate in deficient cells was 1.5 to 1.7 times higher than in the control cells. A similar difference in ${ }^{65} \mathrm{Zn}$ uptake rate, viz. a factor of 2.1 , was demonstrated when incubating in a standardized, near physiologic medium, instead of plasma (Table 7). In the animals, the in vivo uptake increased by a factor of approximately 8 during low dietary $\mathrm{Zn}$ intake (Table 5). This factor is partly due to lower total plasma zinc (reduction $0.011 / 0.022=0.5$ ) and higher plasma ${ }^{65} \mathrm{Zn}$ activity (increase $8.9 / 3.8=2.3$ ) leading to an increased sp act (increase $2.3 / 0.5=4.7$ ). In case of equal in vivo uptake rates, the uptake rate of ${ }^{65} \mathrm{Zn}$ would have been 4.7 times higher. However, as mentioned, a factor of 8 was found, indicating that the ${ }^{65} \mathrm{Zn}$ uptake rate of deficient erythrocytes increases by a factor of 1.7. Thus, the in vivo and in vitro results for erythrocyte ${ }^{65} \mathrm{Zn}$ uptake agree well. However, this agreement may be artificial, because the in vivo uptake might be influenced by factors that are absent in vitro, e.g. the differences in the rate 
Table 5. Organ distribution of ${ }^{65} \mathrm{Zn} 30 \mathrm{~min}$ after oral dose in male weaning rats pair-fed zinc-deficient or control diets for $10 d$ (mean $\pm S D ; n=12$ )

\begin{tabular}{|c|c|c|c|c|c|c|c|c|}
\hline \multirow[b]{3}{*}{ Tissue } & \multicolumn{8}{|c|}{ Tissue ${ }^{65} \mathrm{Zn}$ activities } \\
\hline & \multicolumn{4}{|c|}{$\%$ of dose administered } & \multicolumn{4}{|c|}{$\%$ of activity in animal } \\
\hline & Deficient* & Control* & $p$ & $\mathrm{O}+$ & Deficient & Controlf & $p$ & $\mathrm{O}$ \\
\hline Small intestine & 5.2 & 4.5 & NS & 63 & 5.8 & 8.4 & $\S$ & 66 \\
\hline Plasma & 8.9 & 3.8 & $\|$ & 6 & 9.3 & 7.6 & NS & 56 \\
\hline Erythrocytes & 0.89 & 0.11 & $\|$ & 0 & 0.81 & 0.15 & $\|$ & 4 \\
\hline Liver & 11 & 11 & NS & 99 & 12 & 22 & $\|$ & 7 \\
\hline Pancreas & 0.72 & 0.28 & $\|$ & 8 & 0.87 & 0.60 & $\S$ & 40 \\
\hline Bone & 17 & 8.8 & $\S$ & 50 & 19 & 18 & NS & 76 \\
\hline Muscle & 33 & 13 & $\|$ & 9 & 36 & 27 & $\S$ & 3 \\
\hline Total for tissues sampled & 77 & 41 & $\|$ & 14 & 84 & 84 & & \\
\hline Whole body ${ }^{65} \mathrm{Zn}$ & $92 \pi$ & $49 \pi$ & & & $100^{* *}$ & $100^{* *}$ & & \\
\hline
\end{tabular}

* Values rounded according to counting errors.

$\dagger$ Percentage overlap.

$\ddagger$ Total tissue ${ }^{65} \mathrm{Zn}$ activities $0.5 \mathrm{~h}$ after an ingested dose, mean value $(n=12)$ in $\%$ absorption, by separate calculations.

$\S p<0.01$ (analysis of variance).

$\| p<0.001$ (analysis of variance).

II Taking into account that $83.5 \%$ of the animal was sampled and that for the whole body a correction factor of $100 / 83.5$ was applied.

** Set to $100 \%$.

Table 6. Sp act of ${ }^{65} \mathrm{Zn} 30$ min after oral dose in tissues of male weaning rats pair-fed zinc-deficient or control diets for $10 \mathrm{~d}$ $(m e a n \pm S D ; n=12)$

\begin{tabular}{lccccc}
\hline & \multicolumn{4}{c}{ Tissue sp act $\left(\mathrm{kBq}^{\left.{ }^{65} \mathrm{Zn} / \mu \mathrm{mol} \mathrm{Zn}\right)}\right.$} \\
\cline { 2 - 6 } \multicolumn{1}{c}{ Tissue } & Deficient & Control & $p$ & $\mathrm{O}^{*}$ & deficient/control \\
\hline Small intestine & $6.8 \pm 0.4$ & $5.7 \pm 0.4$ & $\dagger$ & 62 & 1.2 \\
Plasma & $32.4 \pm 7.2$ & $7.3 \pm 2.0$ & $\ddagger$ & 0 & 4.4 \\
Erythrocytes & $0.3 \pm 0.08$ & $0.04 \pm 0.01$ & $\ddagger$ & 0 & 7.5 \\
Liver & $1.3 \pm 0.2$ & $1.3 \pm 0.2$ & NS & 99 & 1.0 \\
Pancreas & $13.6 \pm 0.8$ & $0.4 \pm 0.04$ & $\ddagger$ & 0 & 37.8 \\
Bone & $0.14 \pm 0.02$ & $0.05 \pm 0.01$ & $\ddagger$ & 6 & 2.8 \\
Muscle & $0.8 \pm 0.07$ & $0.28 \pm 0.03$ & $\ddagger$ & 6 & 2.9 \\
Overall & 35.0 & 16.5 & & & 2.1
\end{tabular}

* Percentage overlap.

$\dagger p<0.01$ (analysis of variance)

$\ddagger p<0.001$ (analysis of variance).

Table 7. Uptake of ${ }^{65} \mathrm{Zn}$ in vitro by erythrocytes from male weaning rats pair-fed zinc-deficient or control diets for $10 d^{*}$

\begin{tabular}{lccrrr}
\hline & $\begin{array}{c}\text { Deficient } \\
\text { erythrocytes }\end{array}$ & $\begin{array}{c}\text { Control } \\
\text { erythrocytes }\end{array}$ & $n \dagger$ & $p$ & O \\
\hline Uptake from: & & & & & \\
Deficient plasma & $9.4 \pm 0.2$ & $6.2 \pm 0.2$ & 3 & $\S$ & 0 \\
Control plasma & $8.0 \pm 0.2$ & $4.7 \pm 0.2$ & 3 & $\|$ & 0 \\
Medium & $8.9 \pm 2.7$ & $4.3 \pm 1.8$ & 12 & $\|$ & 2 \\
Medium, erythrocytes & $9.2 \pm 2.8$ & $4.4 \pm 2.0$ & 6 & $\|$ & 2 \\
$\quad$ postendotoxin & & & & &
\end{tabular}

* Uptake rate is given as \% dose/h (mean $\pm \mathrm{SD})$.

$\dagger$ Number of determinations.

$\ddagger$ Percentage overlap.

$\S p<0.01$ (analysis of variance).

$\| p<0.001$ (analysis of variance).

of appearance and disappearance of the ${ }^{65} \mathrm{Zn}$ activity in the plasma, the total zinc level in plasma, and the various chemical forms in which both ${ }^{65} \mathrm{Zn}$ and $\mathrm{Zn}$ occur in plasma within $30 \mathrm{~min}$ postdose. The findings for the in vivo situation in animals are in line with the results in man of Wastney et al. (10), who demonstrated lower in vivo erythrocyte ${ }^{65} \mathrm{Zn}$ uptake during supplementation.

The results of these experiments show that the difference in erythrocyte ${ }^{65} \mathrm{Zn}$ uptake is not due to differences in ghost bound activity: the ${ }^{65} \mathrm{Zn}$ activity in the ghosts is equal for both groups. Finally, the increase in erythrocyte ${ }^{65} \mathrm{Zn}$ uptake during deficiency is unaffected by endotoxin, which alters the whole body ${ }^{65} \mathrm{Zn}$ absorption, excretion, and turnover (4).

Diagnostic implications. In our previous study involving prolonged, clinical zinc deficiency, significant differences in the specific zinc activity in plasma have been observed after $21 \mathrm{~d}$. The present study demonstrates that significant differences in plasma sp act also occur in the situation of an early subclinical deficiency. Thus, differences in specific zinc activity in plasma shortly after administration of radioactive zinc may form the basis of a clinical test. However, the clinical applicability of radioactive zinc for diagnostic purposes in vivo is limited, and restricted to the critically ill. A way out is the use of isotopically enriched stable zinc isotopes. A serious drawback of this latter method is its elaborate and time-consuming character, entailing high costs and highly specialized laboratories.

The present study demonstrates that early, subclinical deficiency causes an increased erythrocyte ${ }^{65} \mathrm{Zn}$ uptake. Because this effect occurs also in vitro, it may be used as a basis for a clinical test to detect subclinical deficiency. Such an in vitro test has the advantage that no radioactivity is administered to patients. Furthermore, the test is simple to perform, requiring only a small amount of erythrocytes, which usually go to waste in routine clinical laboratories. Therefore, we advocate the erythrocyte ${ }^{65} \mathrm{Zn}$ uptake as a test to detect early, subclinical zinc deficiency.

In our animal model, increased in vitro erythrocyte ${ }^{65} \mathrm{Zn}$ uptake appears to be sensitive and specific. Being an in vitro test, only erythrocyte properties are tested. Neither plasma nor other tissues may influence the results in an uncontrolled manner as is the case for in vitro whole blood ${ }^{65} \mathrm{Zn}$ uptake. Endotoxin does not affect the uptake results if performed in nearly physiologic medium, whereas it does disturb the whole blood ${ }^{65} \mathrm{Zn}$ uptake $(11,12)$.

\section{REFERENCES}

1. Van Wouwe JP 1989 Clinical and laboratory diagnosis of acrodermatitis enteropathica. Eur J Pediatr 149:2-8

2. Walravens PA, Hambidge KM 1976 Growth of infants fed a zinc supplemented formula. Am J Clin Nutr 29:1114-112

3. Walravens PA, Krebs NF, Hambidge KM 1983 Linear growth of low income preschool children receiving a zinc supplement. Am J Clin Nutr 38:195-201

4. Van Wouwe JP, Veldhuizen M, Van den Hamer CJA, de Goeij JJM 1990 Discrimination between low dietary zinc and endotoxin exposure. Pediatr Res 28:332-335 
5. Van Herck H. Van Wouwe JP. Veldhuizen M. Baumans V. Stafleu FR. Beynen AC 1989 Clinical examination of weanling rats with early zinc deficiency. Lab Anim 23:328-332

6. Van Wouwe JP. Veldhuizen M. De Goeij JJM. Van den Hamer CJA 1990 In vitro exchangeable ernthrocutic zinc. Biol Trace Elem Res 25:57-69

7. White CL 1988 The effect of zinc deficiency on the body composition of rats. Biol Trace Elem Res 17:175-187

8. Van Barneveld AA 1983 Trace element absorption and retention studies in mice. Thesis. Catholic University of Nijmegen. the Netherlands
9. Hartz AJ 1984 Overlap index. Arch Pathol Lab Med 108:65-67

10. Wastney ME. Aamodt RL. Rumble WF. Henkin RI 1986 Kinetic analysis of zinc metabolism and its regulation in normal humans. Am J Physio 251:R398-R408

11. Berry RK. Bell MC. Wright PL 1966 Influence of dietary calcium. zinc. and oil upon the in vitro uptake of zinc- 65 by porcine blood cells. J Nutr $88: 284-$ 290

12. Chesters JK. Will M 1978 The assessment of zinc status of an animal from the uptake of ${ }^{65} \mathrm{Zn}$ by the cells of whole blood in vitro. Br J Nutr 38:297-306 